of $137 \mathrm{~g}$; with unripe banana these data were $86 \mathrm{~g}$ of crude protein after an intake of ro4 $\mathrm{g}$ and with silaged banana, $83 \mathrm{~g}$ following an intake of $77 \mathrm{~g}$ of total crude protein.

With banana, the fermentations in the rumen were less important and more regular during the day than with barley diets (total VFA; I $27 \mathrm{~m}$ eq/l with barley, I 5 and I I. $\mathrm{m}$ eq/l with unripe or silaged banana); the amounts of total volatile bases released were practically non existent in the case of banana and about $20 \mathrm{mg}$. nitrogen/ $100 \mathrm{ml}$ of juice in the case of barley diets.

\title{
MORPHOLOGIE INTESTINALE CHEZ LA LAPINE GESTANTE ET ALLAITANTE SELON LE NIVEAU D'ALIMENTATION
}

\author{
F. LEBAS et J.-P. LAPLACE* \\ Station de Recherches sur l'Élevage des Porcs, \\ * Laboratoire de Physiologie de la Nutrition, \\ Centre national de Recherches zootechniques, I. N.R. A., \\ 78350 Jouy en Josas
}

L'existence chez nombre de mammifères de modifications morphologiques du tube digestif au cours du cycle de reproduction est un fait unanimement reconnu. Une revue détaillée de ces phénomènes a été réalisée par FELL ( ${ }^{1}$ ), principalement dans le cas de la brebis, de la ratte et de la souris. Cependant, l'allure de ces phénomènes est loin d'être univoque, laissant place à de nombreuses différences inter-spécifiques. L'évolution des mensurations viscérales au cours de la croissance ayant été précisée antérieurement $\left({ }^{2}\right)$, nous avons abordé dans la présente étude les modifications de poids et de longueur de l'intestin grêle au cours d'un cycle de reproduction chez la lapine.

A compter de la saillie, les lapines ont été soit nourries à volonté jusqu'au sevrage, soit rationnées à $140 \mathrm{~g} /$ jour d'un même aliment pendant la gestation puis alimentées à volonté dès la mise bas. Cinq lapines ont été abattues aussitôt après la saillie ; 5 lapines par niveau d'alimentation ont été sacrifiées à chacun des 6 stades suivants : 10, 21 et 28 jours de gestation ; 10, 21 et 32 jours après la mise-bas. Les techniques de mesure ont été décrites antérieurement $\left({ }^{2}\right)$.

La longueur de l'intestin grêle est, au $28 \mathrm{e}$ jour de la gestation, accrue de I I p. Ioo chez les lapines rationnées, et réduite de $9 \mathrm{p}$. Ioo chez les lapines ad libitum par rapport au stade saillie. La longueur culmine pour les 2 populations ro jours après la mise bas. Le poids de l'intestin grêle chez les lapines ad libitum est réduit au cours de la gestation ( I I et $14 \mathrm{p}$. Ioo respectivement à $2 \mathrm{r}$ et 28 jours), et accru de 4I p. Ioo 2I jours après la mise bas. Chez les lapines rationnées on n'observe pas de régression pendant la gestation, et un moindre accroissement pondéral durant l'allaitement (27 p. Ioo au $2 \mathrm{I}^{\mathrm{e}}$ jour). La seule modification significative de la longueur du cæcum et du côlon est une réduction de 13 p. Ioo au $28^{\circ}$ jour de gestation de la longueur cæacale chez les lapines ad libitum. Une perte de poids importante du cæcum au cours de la gestation est observée chez toutes les lapines. Elle atteint au $28 \mathrm{e}$ jour respectivement 29 et $3 \mathrm{I}$ p. roo chez les lapines rationnées et ad libitum. Le cæcum retrouve et conserve son poids initial dès le roe jour après la mise bas. Le poids du côlon est toujours réduit pendant la gestation, en particulier chez les lapines ad libitum ( $2 \mathrm{I}$ p. IOo au $28 \mathrm{e}$ jour). Le poids initial est rapidement regagné dès les Io premiers jours de lactation, cette valeur n'étant ensuite guère dépassée.

Globalement, on peut retenir que le rationnement de la lapine pendant la gestation tend à 
réduire l'amplitude des variations pondérales de l'intestin dans son ensemble. Lorsque les poids sont rapportés au poids vif, vide de contenus digestif et vésical, les tendances à la régression en fin de gestation et à la croissance viscérale pendant la lactation sont accentuées.

\section{RÉFÉRENCES BIBLIOGRAPHIQUES}

(I) Fell B. F., 1972. World Rev. Nutr. Diet., 14, 180-256.

(2) Lebas F., LAptace J. P., I972. Ann. Zootech., 21, 37-47 et 505-524.

\section{SUMMARY}

\section{INTESTINAL MORPHOLOGY IN THE PREGNANT} AND LACTATING RABBIT ACCORDING TO THE LEVEI, OF FEEDING

In many mammals, the existence of some morphological modifications of the gut during the reproductive cycle is a well known fact. A detailed review of these phenomena has been made by Fell ( $\left.{ }^{(}\right)$, mainly in the case of the Ewe, the Rat and the Mouse. However, many inter-specific differences do exist and the interpretation of such phenomena is difficult. The visceral developments during growth having been precised in a previous work $\left(^{2}\right)$, we trie 1 , in this study, to show the weight and length changes in the small intestine during one reproductive cycle.

From mating, female rabbits were either fed ad libitum until weaning or restricted during pregnancy down to $\mathrm{I} 4 \mathrm{O} \mathrm{g} /$ day with the same feed, then fed ad libitum immediately after parturition. Five rabbits were slaughtered just after mating, 5 rabbits per feeding level were slaughtered at each of the 6 following stages : ro, 21 and 28 days of pregnancy; ro, 21 and 32 days after parturition. The measuring techniques have been described in a previous work $\left({ }^{2}\right)$.

The small intestine length on day 28 of pregnancy was increase $d$ by I I p. Ioo in the restricted animals and reduced by $9 \mathrm{p}$. 100 in the ad libitum fe 3 rabbits, as related to the moment of mating. The length reached a maximum in both populations ro days after parturition. The small intestine weight in the ad libitum fed rabbits was reduced during pregnancy (I I and I 4 p. Ioo respectively on days $2 \mathrm{I}$ and 28 ) and increased by $4 \mathrm{I}$ P. IOo, $2 \mathrm{I}$ days after parturition. In the restricted rabbits, we did not observe any regression during pregnancy and a smaller weight increase during lactation (27 p. Ioo at the day 2r). The only significant modification of the cæcum and colon length was a 13 p. Ioo reduction of the caecal length on day 28 of pregnancy in the ad libitum fed rabbits.

A large caecum weight loss during pregnancy was observed in all rabbits. on day 28 , it rached 29 and $3^{\mathrm{I}} \mathrm{p}$. too respectively in the restricted and ad libitum fed rabbits. The caecum recovered and maintained its former weight on day ro following parturition. The weight of the colon was always reduced during pregnancy and especially in the ad libitum fed rabbits ( $21 \mathrm{p}$. Ioo on day 28 ). The former weight was rapidly reached in the first to days of lactation and did not change afterwards.

In conclusion, restriction of the female rabbit during pregnancy leads to a reduction in the amplitude of intestinal weight changes. When weights were expressed as related to live weight without any digestive and visceral contents, tendences towards regression at the end of pregnancy and to visceral enlargment during lactation were more pronounced. 